| SBAD | Sosyal Bilimler Araştırmaları Dergisi

| JSRR | Social Sciences Researches Journal

(Yaz 2018) 13/1:219-235 / (Summer 2018) 13/1: 219-235.

Makale Geliş Tarihi: 07.03.2018 Yayın Kabul Tarihi: 29.06.2018

Doi Number :http:/ / dx.doi.org/10.19129/sbad.356

\title{
BALKAN ÇÖZÜLMESİ VE OSMANLI CEPHESİNDEN BALKAN DEVLETLERI ALGISI
}

Mehmet Ali KARAMAN*

Şark meselesi kapsamında yer alan ve Türk unsurunun Avrupa'dan tasfiyesi amacını taşıyan Balkan Savaşları sonrasında bölgesel etnik temizlik çalışmaları hız kazanmıştır. Bu faaliyetler Balkan Savaşlarıyla sınırlı kalmadığı gibi XX. yüzyılın tamaminda bölgedeki Müslüman unsurlar üzerinde kendini hissettirmektedir. Bu bağlamda Balkanlarda mevcut devletlerin askeri sistemleri ve teçhizat bakımından altyapıları başta Osmanlı Devleti olmak üzere Avrupalı devletlerin de yakından takip ettiği konulardandır. Her biri son derece öneme haiz Balkan devletleri dönemin aydınları ve uzmanları tarafından ayrı ayrı ele alınarak Balkan Savaşları öncesi ve sonrasında çeşitli analizler yapılmaktaydı. Hayati öneme sahip Balkanların kontrolünden çıkması ihtimali ve doğuracağı sonuçlar Osmanlı Devleti'nin siyasi ve askeri otoriteleri tarafından ilk başlarda akla getirilmedi. Ancak alınan sonuçlar ve ihtimal verilmeyen çözülme gerçekleştikten sonra yapılan yorumlar gazete sütunlarında ve daha sonraki dönemlerde hatıratlarda yer aldi.

Bu çalışmada Balkan Devletlerinin silah, mühimmat ve bölge hâkimiyetleri, askeri talim ve sistemleri ile alakalı genel durumları dönemin devlet adamları tarafından yapılan değerlendirmeler çerçevesinde ele alınmıştır. Öte yandan karşılıklı olarak Balkanlarda bulunan Müslüman unsurların tahliyesinin ve Osmanlı topraklarındaki Balkan menşeili Gayrimüslimlerin durumları Osmanlı Arşivi vesikaları, dönemin devlet adamları ve askerlerin görüşleri dahilinde incelenmiştir.

Anahtar Kelimeler: Balkanlar-Askeri Tarih- Balkan Savaşları.

\section{DISINTEGRATION OF THE BALKANS AND PERCEPTION OF BALKAN STATES FROM THE OTTOMAN FRONT}

Regional ethnic cleansing works accelerated after the Balkan Wars within the context of the eastern question and aiming to eliminate the Turkish element from Europe. These activities did not remain limited with the Balkan Wars, but they also became efficient on Muslim elements in the region throughout the $20^{\text {th }}$ century. In this context, the military systems and equipment infrastructure of the existing states in the Balkans are the issues closely followed by the European states, and the Ottoman Empire being in the first place. The Balkan States, each of which was highly important, were separately discussed by the intellectuals and experts of that

\footnotetext{
* Dr. Mehmet Akif Ersoy Üniversitesi, Fen Edebiyat Fakültesi, Tarih Bölümü karaman@mehmetakif.edu.tr
} 
period, and various analyses were conducted before and after the Balkan Wars. The possibility of the Ottoman Empire losing the control of the Balkans having vital importance and its results were not initially suggested by the political and military authorities of the Empire. However, comments made after the results obtained and the disintegration which had never been regarded possible took place were found in newspaper columns and memories in the later periods.

In this study, weapons, ammunition and territorial dominance of the Balkan States and their general conditions related to military training and systems were discussed within the framework of evaluations made by statesmen of that period. On the other hand, the evacuation of Muslim elements in the Balkans and the conditions of non-Muslims of the Balkan origin in the Ottoman territories were examined within the scope of Ottoman archive documents and the opinions of statesmen and military men of that period.

Key Words: Balkans-Military History- Balkan Wars.

\section{GİRIŞ}

Balkan terimi hakkında çok farklı tanım ve etimolojik araştırmaya rastlamak mümkündür. Balkan kelimesi sıra dağ veya dağlık anlamına gelen Türkçe sözcüktür. (İnalcık, 2005: 20). Balkan adının Osmanlıların bölgeye gelmesinin ardından kullanılmaya başlandığı ve çamur anlamina gelen "Balk" kelimesinden türetildiği kabul edilen tanımlardandır. Adını batıdan doğuya uzanan ve Bulgaristan'ı ikiye bölen dağ silsilesinden alan Balkan yarımadasının doğu, güney ve batı sınırları hakkında mevcut görüş birliğine rağmen kuzey sınırları tartışmalıdır. (Karpat, 1992: 25). Başbakanlık Osmanlı Arşivinde bulunan 1565 tarihli bir belgede Balkan sözcüğü bugün Bulgaristan sınırlarında olan Triavna'nın olduğu yerde Derbentçi köyünün kurulduğu dağ adı olarak geçer.(Todorova, 2012:12).

Balkan Savaşları, Osmanlı Devleti'nin parçalanma sürecinin önemli basamaklardan birini teşkil eder. Osmanlı Devleti'nin kalbi sayılan Balkanlardaki hareketlenme, dönemin siyasi ve sosyal hayatının en önemli gündemini oluşturmaktadır. Çok farklı milletlerin barındığı Balkan topraklarının kopma süreci oldukça sancılı bir dönem yaşanmasına sebebiyet verdi. Balkanların kaybı, yakın zamanda Osmanlı'ya bağlı benzer unsurların da ayrışacağının habercisi olma niteliği taşımaktadır. Osmanlı Devleti'nin Balkan hassasiyeti belki de kaybetmeye başladığı ilk bölge olması münasebetinden gelmektedir.

Balkan Savaşları, Osmanlı Devleti'nin yıkılmasını değil, Balkanlardaki Türk anavatanının kaybedilmesine sebep oldu. Balkan Savaşları'nın meydana getirdiği geri çekilme, göç ve ağır insani kayıplar son yüzyıllık Türk tarihinde tamir edilemez yaralar meydana getirmiştir. XX. yüzyılda yaşanılan göçler sonrası Türkiye'de yaşayan halkların köken itibarıyla en az üçte birinin Balkanlardan göçle geldiğini söylemek mümkündür. Cumhuriyetin ilk yıllarında Çukurova, Marmara, Ege ve Trakya bölgeleri başta olmak üzere ülkenin pek çok yerine Balkanlardan göç alınmıştır. Bununla birlikte bugünkü Balkan devletlerinin bazılarında Türkler ve Müslümanlar ciddi bir azınlık olarak durmaktadırlar. Bu yönüyle Balkan sorunu bitmeyen bir sorun olarak devam etmektedir. Balkan meselesini Avrupa'nın zihin ve fikir yapısı da sürekli 


\section{Balkan Çözülmesi ve Osmanlı Cephesinden Balkan Devletleri Algısı}

körüklemiştir. Nitekim 1908 yılında Allen Upward, Balkanları, Türk Avrupası olarak tasvir etmiştir. Upward, "Balkan dünyasının gözünde tanr rolünü oynayan Avrupa Adriyatik'te sona erer. Balkanlar Avrupa'nın bir parçası sayılmaz. Balkanlılar için Avrupalı, Bizanslılar için Frank'ın taşıdığı anlamı taşır. Kısaca Avrupa Latin Hristiyan dünyasıdır" diyerek Balkanları Avrupa'dan tecrit etmektedir. (Çağ, 2012: 12). Bu şekilde tecrit edilen Balkanlılar kendilerini bu tasnifin dışında tutmak için bir mücadele vermek gereğini duymuşlardır. Avrupa sürekli olarak Balkanları tahkir amaçlı, "Balkanlaşmak" kelimesiyle ifade etmiştir ${ }^{1}$.

Balkan Savaşları XIX. yüzyılın bütün belirgin özelliklerini içerisinde barındıran bir savaştır. Bu savaş, XIX yüzyıldaki Balkan Savaşlarının ve daha genel olarak, XX. yüzyıl öncesinde ve sonrasında uluslararası güç sisteminin yol açtığı savaşların bir devamıdır(Hobsbawm, 2007: 17). Osmanlı Devleti'nin kalbi sayılan Balkanlar'daki hareketlenme, dönemin siyasi ve sosyal hayatının en önemli gündemini oluşturmaktadır. Çok farklı milletlerin barındığı Balkan topraklarının kopma süreci oldukça sancılı bir dönem yaşanmasına sebep olmuştur. Balkan Savaşlarıyla birlikte Edirne serhat şehri olarak anılmaya başlamıştır. Balkan topraklarının kaybı, yakın zamanda Osmanlı'ya bağlı benzer unsurların da ayrışacağının habercisi olma niteliği taşımaktadır.

Uluslararası kamuoyunda geniş yer verilen Balkan Savaşları öncesinde belli hazırlık ve planların yapıldığı, isyanların masa başında tertiplendiği, isyancıların ise özellikle Rusya'dan, zaman zaman Avusturya ve İtalya'dan destek bulduğu görülmektedir. Balkan milletlerinden olan ve Osmanlı için her dönemde ayrı bir öneme sahip olan Arnavutluk bölgesindeki isyan girişimi, Osmanlı merkezini o günlerin yaşanılan sorunları arasında her şeyden daha çok tedirgin etti. Balkanlarda çıkabilecek olası bir isyan ve çözülme durumunun bütün memleketi saracağı bilinciyle hareket eden Osmanlı diplomasisi yurtdışında çeşitli çalışmalar yaptı. Yurt içinde kamuoyu üzerinde olumlu tesir uyandıracak çeşitli girişimlerin yanı sıra, basın ve yayın organlarında Balkanlar ile ilgili çok sayıda yazı dizisi ve makale yayınlandı. Tedbir amaçlı bölgeyi yakından ilgilendirecek pek çok girişimde bulunulmasının yanında olası bir harp ile ilgili de çeşitli önlemler alınma yoluna gidilmiştir. Bölgeye yapılan diplomatik ziyaretler, bizzat Sultan Reşad'ın Haziran 1911 tarihli Rumeli seyahati bu teşebbüslerden en bilinenidir.

Balkan savaşları öncesi savaş sinyallerin alınması Balkanlarda yaşayan unsurların hareketlenmelerine, dolayısıyla kendi silahlı kuvvetlerinin altyapılarının oluşturulmasına ortam hazırlamıştır. Muhtemel ittifakların yanında Balkanlardaki Panslavist örgütlenmenin tesiri kendini hissettirir niteliktedir. Başta Rusya ve İtalya olmak üzere pek çok güçlü devletin hesap yaptı̆̆ı Balkan topraklarının muhafaza çabası Osmanlı İmparatorluğu'nun parçalanma sürecine girmesinde önemli bir aşama teşkil etmiştir. Bölgedeki unsurların dirlik ve düzenlerinin korunması Osmanlılar için

1 "Balkanlaşmak" tabiri ilk olarak I. Dünya Savaşı sonrasında ortaya çıkmış, 20 Aralık 1918'de New York Times gazetesinde kullanılmıştır. Avrupa'nın Balkanlaşması yolunda olduğu şeklinde yorumlar yapılmıştır.

| Sosyal Bilimler Araştırmaları Dergisi 
bir isyanın bastırılması, Balkan milletleri açısından ise bağımsızlık mücadelesi olarak ortaya çıkar. Burada konuya hangi pencereden bakıldığı elbette önemlidir.

Batı tarafından "Şark Meselesi" olarak adlandırılan ve ilk başlarda suni bir slogandan öteye gitmeyen mesele Balkanların elden çıkmasıyla evvela Büyük bir İmparatorluğun marazlı bir devlet haline rücu' etmesine, daha sonra da parçalanıp yok olmasına sebebiyet vermiştir. Bu parçalanma elbette oldukça sancilı zamanların yaşanmasına sebep oldu. Bunda da en çok bedel ödeyen Balkanlarda yüzyıllarca varlık gösteren Müslümanlardır. Balkan savaşlarıyla başlayan etnik temizlik süreci 1990 'l 1 yıllara gelinceye kadar devam etmiş, gelecekte de kalıcı barışa dair olan inancın bir beklenti ve ümit etmenin ötesine geçemediği fanatik siyasilerin zaman zaman açıklamalarındaki satır aralarında kendini hissettirmektedir. Değişen dünya düzeni içerisinde XX. yüzyılın son çeyreği Balkanlardaki çözülmenin daha da devam edeceğini dünyaya gösterdi. Sırp, Hırvat ve Boşnak unsurların birbirleri ile olan katı mücadelesi beraberinde bir katliam yaşanmasına da neden oldu. Akabinde yeniden yapılanan Balkan coğrafyası neredeyse her köşesinde son yüzyılın yorgunluğunu taşımakla beraber gerginliğini de korumaktadır.

\section{Balkan Çözülmesi}

XX. yüzyılda Balkan milletleri her ne kadar Osmanlı karşıtı bir durum sergilemişlerse de esas itibarıla birbirleriyle de dengeli bir zıtlık esasına dayalı bir diplomasi sürdürmüşlerdir. Etnik, dini ve sosyal açıdan oldukça farklı unsurlar olan bu milletlerin her biri diğerinden zaman zaman nefret ettiğini gizlememiştir. Balkan coğrafyasıyla yakın ilişkide olup ama kendini asla Balkan saymayan Romanyalılar Balkan olmak şöyle dursun, Balkan ulusları ile alakalı sürekli nefret söylemleri sarf etmektedirler. Bulgar, Yunan, Sırp ve Karadağlılar dışında Romanya israrla Balkanlı olmadığını ifade etmek zorunda kalmıştır. Nitekim I. Dünya Savaşı yıllarında Bükreş'ten haberler ileten John Reed şöyle demiştir: "Bir Romen'i kızdırmak isterseniz, ülkesinin bir Balkan devleti olduğunu söyleyin. Romanya bir Balkan devleti değildir. Bizi vahşi Yunanlılarla, Slavlarla nasıl karıştırırsınız! Biz Latin'iz!" (Todorova, 2012:102).

Osmanlı Devleti'nde ise Balkan birliğinin bozulması ve bölgenin kaybı asla kabul edilebilecek bir durum değildi. Toplumun hiçbir kesimi bu durumu hazmedemediği gibi ilk başlarda Balkanlardaki olası bir ayrışmaya ihtimal dahi verilmemekteydi. Öyle ki Balkan coğrafyasının pek çok merkezi Osmanlı Devleti'nin en önemli şehirleri arasında gösterilir idi. Başta Selanik, Manastır, Resne, İşkodra, Sofya, gibi bölgeler Osmanlı'ya sembol olmuş merkezler arasındaydı. Bir başka konu ise Osmanlı asker ve bürokrasisinin önemli bir kesimi ile XX. yüzyıl başlarında adından çokça söz ettiren İttihat ve Terakki Cemiyeti kadrolarındaki önemli isimlerinden birçoğu Balkan kökenli idi. Bunun neticesi olarak da Balkanlar daha bir önem arz etmekteydi.

1905 yılındaki Rus-Japon harbinin mağlubu olan Rusya Uzakdoğu'da ilerleyemeyeceğini anlayınca yönünü dolayısıyla da politikalarını bütünüyle Balkanlara çevirdi. Aynı yıllarda Balkanlarda beklenti içerisine giren bir başka devlette Avusturya-Macaristan İmparatorluğu oldu. Avusturya-Macaristan İmparatorluğu 5 Ekim 1908 yılında Bosna-Hersek'i ilhak ederek bölge ile yakından ilgilendiğini 


\section{Balkan Çözülmesi ve Osmanlı Cephesinden Balkan Devletleri Algısı}

gösterdi. Bir başka hesap peşinde olan devlet ise İtalya'dır. İtalya'nın Arnavutluk üzerindeki hesapları ile birlikte direk olarak Karadağ ile ilgilenmesi gözlerden kaçmayan önemli müdahalelerdir. Bütün bunların yanında İngiltere de Avrupa'nın eşiğinde olan biteni yakından takip etmekle kalmayıp bölgedeki hareketlenmede söz sahibi olmak gayesiyle diplomatik anlamda ciddi bir müdahildir.

Balkanlardaki gayrimüslim unsurlar için bağımsızlık, Osmanlı açısından isyan sayılacak bir olaya verilecek farklı bir isim "Balkan Çözülmesi" şeklindeki bir yaklaşımla ifade edilebilir. Osmanlı Devleti diğer Balkan devletlerine de ayrıldıkları halde düşman gibi görmüyordu. Siyasi ve iktisadi ilişkilerini devam ettirmiş, Balkan Savaşı öncesine kadar ticaret antlaşmaları yapmıştı. Balkan halklarının Avrupa'daki fikir hareketlerinden etkilenmeleri ve Rusya' nın bölgede yaşayan akraba topluluklarla olan bağlarını güçlendirme girişimleri bu çözülmeye ivme kazandıran faktörlerdendir. Rusya' nın bölgede bulunan Slavlar ile akraba olduklarını hatırlaması bölgenin Osmanlı kontrolüne girişinden yaklaşık dört yüz yıl kadar sonra olmuştur. Bunda da yukarıda da zikredilen Avrupa merkezli bağımsızlık cereyanlarının yanı sıra, zayıflamaya yüz tutmuş bir Osmanlı iktisadi, askeri ve siyasi zafiyeti etkilidir.

Balkanların en hararetli günlerini yaşadığı bir dönemde Mümtaz Kolağası rütbesinde Ahmed Muhtar isimli bir zabitin dönemin askeri yayın organlarından olan Metin Gazetesi'ne yazdığı 'Balkan İttihadı' başlıklı yazı Osmanlı subaylarının duruma bakışını anlatması açısından son derece dikkate şayandır. Makalede;

.. Balkanlar'da hükümfermâ olacak ittihattan bahs edelim: bu şimdilik bir ihtimal ve belki de husule müsskül bir emel-i hayaldir. Fakat her halde bir temenni-i muhâl değildir. Herkese malûmdur ki Balkan yarımadasında bizden başka Romanya, Bulgaristan, Sirbistan, Karadağ ve Yunan hükümetleri vardır. Bunların ahalisi bizim yabancilarımız değildir. Hürriyet ve müsavat sancaklarn altında bugün hakiki manada kardeş olan Osmanlılar dünkü kardeşleridirler. Farkları ancak istihsal-ı hürriyette kendi hesaplarına iş görmekte daha evvel davranmış olmalarıdır.

Bu gün Osmanllarnn, cins ve mezheb, meslek ve meşreb farklılıkların bir tarafa bırakarak yekdiğeriyle nasıl öpüşüp kucaklaştıkların ve ruhlarının bütün temayülat-ı samimiyeleriyle selsebil ittihadın nevâz-ı şikâr cereyanlarına nasıl vakf ve vücûd ve teslim-i nefs ettiklerini görüp anlıyoruz. Şu halde demek oluyor ki, İttihatta şart milletin mutabakatı değil, muvaffakiyetidir. (Ahmed Muhtar, 1908: 2).

Balkan toplumlarının birbirlerine benzerliği, hatta bir Osmanlı gibi yaşam tarzlarını belirledikleri bilinen gerçeklerdir. Motif olarak benzer folklorik özelliklere sahip olan Balkan toplumları aslında birbirlerine karışmamaya özen göstermişlerdir. Osmanlı İmparatorluğu'nun hiçbir şekilde asimilasyon politikasına girmediği yaklaşık beş yüz yıllık Balkan hâkimiyeti bağımsızlık hareketleriyle hızlı bir şekilde sonuçlanmıştır. Bölge halklarının kendi yaşam tarzlarını korumaları, dillerini konuşabilmeleri ve özellikle dini açıdan ibadet serbestisi bunun açık göstergesidir. Ne Avrupalı ne de şark kültürüne dâhil tutulan Balkanlar aslında kendine özgü duruşlarıyla ayrı bir topluluk ve coğrafya olma özelliklerini sürdürdüler(Şahin, 2015: 317). Osmanlı hükümdarları İslamiyet'e mensup ve devletlerini şeri' hükümlerle yöneten kişilerdi. Ancak farklı din mensupları yapılarını korumakla güçlü ve ayrı bir

| Sosyal Bilimler Araştırmaları Dergisi 


\section{Mehmet Ali KARAMAN}

kimlik sahibi olmayı da sürdürmüşlerdir. Osmanlı'da tüm dini grupların fertlerini bir kazanda eriterek tek ulusa dönüştürmek gayreti güdülmedi. Yüzyıllar süren Osmanlı yönetimi sırasında birçokları İslamiyet'i seçti, fakat insanlar buna teşvik edilmedi(Mccarthy, 2012: 7).

Sır Edwın Pears² Balkan halklarını konuşulan dillere ve inandıkları dinlere göre sınıflandırmanın mümkün olduğundan bahsetmiştir. Balkan halklarının dillerinin genel olarak Slav, Latin kökenli, Rumca, Arnavutça ve Türkçe olarak beş ayrı grupta toplamak mümkündür. Osmanlı toplumundaki milletleri dil farklılıkları nedeniyle kaynaşmalarının mümkün olmadığına dikkat çeken Pears, dilleri kadar ırk farklılıkları da bu karışmayı engellemiştir demektedir.(Şahin, 2015: 322).

Balkan çözülmesine kıvılcım sayılabilecek hareketlenmelerin temelinde Balkan devletlerinin Batılı devletlerin tesirine girmeleri yatmaktadır. Avrupa'da gelişen ulusçu cereyanlara Rusya'nın tesiri ve katkısının da eklenmesiyle bölgede ilk başlarda görülen zayıf milis ayaklanmalar kısa süre içerisinde düzenli ve destekli bağımsızlık hareketine dönüştü. Rusya'nın bölge üzerindeki tesirleri kabul edilir bir gerçekliktir. Bölgede varlık gösteren Slav milletlerin yanı sıra Antik döneme dayanan tarihlerinden yola çıkarak özelliklerini korumaya çalışan Yunanlıları görmekteyiz. Avrupa'nın büyük desteğini görmüş olan Yunan hareketi başarılı olurken, Balkan Kavimlerinin Osmanlı'ya karşı birlikte hareket etme duygusunun da temeli atıldı. Yunan'dan sonra belki de en önemli uyanma Bulgarlarda oldu. Çünkü Yunan bağımsızlığı Balkan halkaları arasında zaten var olan gizli milliyetçilik duygularının açığa çıkmasına sebep olmuştur.

Avrupa'da ayrılıkçı milliyetçiliğin patlaması XX. yüzyılda daha da özgül tarihsel köklere sahiptir. Versailles ile Brest Litovsk'un sonuçları hala kendini hissettirmektedir. Özünde Habsburg ve Türk imparatorluklarının kesin çöküşü ile Çar yanlısı Rusya imparatorluğunun kısa süreli çöküşü, kitlesel cinayetler ya da mecburi toplu göçler dışında uzun vadede çözümü bulunmayan türden problemlerle uğraşan bir dizi benzer ulus devlet ortaya çıkmıştır.( Hobsbawm , 2010: 196). Osmanlı Balkanlarının çözülme sürecini Louis Renault ${ }^{3}$ ise “Osmanl İmparatorluğu'nun geniş toprakları, sanki cansız bir maddeyi kesip biçen düzenbazlar tarafindan, oralarda bulunan halkın çıkar ya da duyguları göz önünde tutulmadan paylaştırlmakta, halk geçici heveslerin, heyecanın, siyasal çıkarların dayattı̆̆ı çözümleri kabul etmek zorunda kalmaktadır"(Djuvara, 1999: 10) sözleriyle değerlendirmektedir.

Albert Sorel'in Doğu sorunu Türklerin Avrupa'ya girmeleriyle başlamıştır söylemi Şark Meselesi algısıyla bütünlük arz etmektedir. Balkan çözülmesi de Şark Meselesini hayata geçirilmesinin Avrupa'da mâkes bulan ilk halidir. Öyle ya da böyle Avrupa'nın eşiği sayılan Balkanlardan Türklerin atılması Batı için zaruret teşkil etmekteydi. Çünkü Batının içinde beslediği Türk düşmanlığı Batı ilminin temelini temsil eden birçok bilim adamının fikirlerinde kendini göstermiştir. Erasmus pekte felsefi sayılmayacak bir üslupta Türklere karşı sanki bir iddianame yazmış. Ona göre

\footnotetext{
2 London Daily Gazetesinin Muhabiri, 1873-1915 yılları arasında İstanbul'da yaşamış gazeteci.

3 Elçi, Fransa Hukuk Fakültesi ve Siyasal Bilgiler Okulu Profesörü.
}

\section{Social Sciences Researches Journal}




\section{Balkan Çözülmesi ve Osmanlı Cephesinden Balkan Devletleri Algısı}

“Türkler geçmişleri karanlık barbar insanlardır demekte, Hristiyanların varlıklarını sürdürebilmeleri için Türkleri yok etmek gerektiğini savunmaktadır"(Djuvara,1999: 8).

$\mathrm{Bu}$ ve bunun gibi benzer yorumlar Türk- İslam yaşam tarzının dünyada kendini hissettirdiği andan itibaren Batılılar tarafından pek çok projenin geliştirilmesine neden oldu. Türklerin Anadolu coğrafyasındaki hâkimiyetinin Balkanlara taşması ve sonrasında da Avrupa'yı tehdit etmesi Haçlı seferlerindeki barbar yaklaşımın aslında yüzyıllar sonraki İslami fetih ruhunun engellenmesine yönelik çabanın tezahürü olduğunu göstermekteydi. Haçlı seferleri sonrası Avrupa'da oluşan kargaşa ortamı Türklerin Avrupa'ya ilerlemeleri ve özellikle İstanbul'un fethinden sonra daha realist planlar dâhilinde projeler üretilmesine ortam hazırladı. Bu projeler Türkleri önce Avrupa'dan dolayısıyla da Balkanlardan, daha sonra da Boğazlar merkezli İstanbul ve Anadolu'dan temizleme yönündedir. 1914'te başlayan umumi harp bu yönde gelişmelere sahne olmuştur.

Balkan devletleri arasında bir anlaşma ve birlik oluşturma meydana getirilmesi düşüncesi yeni değildi. Bükreş'teki Osmanlı Elçisi Süleyman Sabit, Hükümet'e gönderdiği 15 Ekim 1879 tarihli bir yazısında Rusya'nın aracılığı ile Bulgaristan, Karadağ, Sırbistan ve Romanya arasında bir konfederasyon kurulması ihtimalinden söz etmektedir. Sözde kalan bu deneme 1891'de Yunan hükümet adamlarından Trikopis tarafından Balkanlar'daki Osmanlı topraklarının paylaşılması için Yunanistan, Bulgaristan ve Sırbistan arasında bir ittifak biçiminde gerçekleşmesi istendi. Bulgaristan'ın direnmesi yüzünden başarılamadı.(Karal, 2011:289).

Osmanlı - İtalyan savaşı sürecinde sürüncemede kalan Balkan ittifakı tasarısının tekrar ele alınmasına yol açtı. 11 Ekim 1911'de Bulgar Dışişleri Bakanı Geşof Fransa'dan Sofya'ya dönerken Belgrad'da vagonunda Sırp Dışişleri Bakanı Milovanoviç ile uzun bir görüşme yaptı. İki bakan Osmanlıların Balkanlardaki topraklarının paylaşılması konusunda prensip anlaşmasına vardılar. Bundan sonra Sofya ile Belgrad arasında çok gizli görüşmeler yapıldı ve iki devleti bağlayan gizli anlaşma 13 Mart 1912'de imzaland1.(Karal, 2011: 292). Bunun haricinde Venizelos'un tutumu ve Yunan Bulgar görüşmeleri Makedonya merkezli çeşitli anlaşmazlıklar nedeniyle ilk başlarda askıda kalmış ise de 29 Mayıs 1912 tarihinde Sofya'da imzalanmıştır.

\section{Balkanlarda Osmanlı Ordusu ve Kamuoyunun Balkan Algısı}

Trablusgarp yenilgisi ve sonrası yaşanılan kriz Osmanlı Devleti nezdinde çok daha farklı bir problemin başlangıcı anlamina gelmekteydi. Bir yandan Kuzey Afrika üzerinde İngiliz ve Fransızlardan farklı bağımsız bir politika geliştiren İtalya'nın saldırıları ve alınan mağlubiyete dair yaşanan sıkıntılar, öte yandan Balkanlarda başta Karadağ olmak üzere diğer devletlere askeri altyapı desteği sağlayan aynı İtalya ile girişilen mücadele söz konusudur. Gelişmeleri takip eden Osmanlı Devleti, Rodos, Sakız, Sisam ve Midilli gibi önemli gördüğü adalara takviye kuvvet sevk etmek ve yine Rodos ve Midilli ile Limni ve Istanköy adalarına silah göndermek suretiyle tedbirler almaya çalışmaktaydı. Sonuçta, önceden adaların Anadolu ile haberleşmesini keserek ve böylece Ege'deki harekâtının Osmanlı Devletince izlenmesine engel olmak amacıyla haberleşme kablo ve istasyonlarını tahrip eden İtalyan Donanması, adaları işgal için

| Sosyal Bilimler Araştırmaları Dergisi 
harekete geçti.(Hayta, 1994: 132). Bu durum Balkanlarda var olan huzursuzluğun hemen güneyinde daha net bir sorun olarak algilanmasina ortam verdi.

Osmanlı Devleti'nin Balkanlardaki toprakları üzerine yapılan anlaşmalar Osmanlı kamuoyunda ciddi bir çatışmanın başlaması için heyecan yaratır olmuştur. Balkanlarda başlayacak olan bir harp ile ilgili çeşitli tedbirler alınmasını savunan çeşitli yazılar kaleme alınırken, sulh yollu tavır sergileyen görüşler de yok değildi. Metin gazetesinde yer alan şu satırlar bir savaşın başlangıcının habercisi niteliği taşımaktadır;

“Önümüzdeki ilkbahar zarfinda bir muharebe karşısında bulunacağımızı söylemek istemiyoruz. Hâli hazırda Hükümet-i Osmaniye ile Balkan Hükümet-i sairesi beyninde harbi intaç edebilecek bir ihtilaf mevcut değildir. Ancak farz edelim ki intizarm hilafinda faraza Yunanistan, Strbiya veyahut Bulgaristan ile harb etmek mecburiyetinde bulunalım. Bu takdirde ne olacak?" (Mehmed Zeki, 1912:1)

Ekim ayı itibarı ile İstanbul'da tansiyon yükselmiş, gazetelerin de ateşli manşet ve hararetli yazılarıyla durum daha farklı bir hal almıştır. Darülfünun öğrencileri harpten yana tavır sergilemiş, harbe girilmesi gerektiği doğrultusunda hükümet kapılarında çeşitli gösteriler tertiplemişlerdir. Aynı günlerde İttihat ve Terakki Cemiyeti halkı birlik beraberliğe davet eden bildiriler yayınlamıştır.

7 Ekim tarihinde göstericilere karşı hükümet binasından bir konuşma yapan Sadrazam Gazi Ahmed Muhtar Paşa "Harp denilen şeyi biz biliriz. Laf ile söylendiği gibi kolay değildir. Harp'ten hem yenen hem yenilen zarar görür. İşte bunun içindir ki en kuvvetli devletler bile harbe girmek için çok düşünmeye mecburdurlar. Harbin iyi taraflarn olduğu gibi fena tarafları da vardır. Hesapsız işe girişilmez. Bu da sizin bileceğiniz şey değildir" sözleriyle irad ettiği nutukta kalabalığ1 teskin etmeye çalışmıştır.(Karal, 2011: 301).

Gazi Ahmed Muhtar Paşa'nın endişeleri arasında belki de savaş öncesinde terhis edilmiş olan 120 tabur ve bundan doğan boşluk yatmaktadır. Ordunun 29 Temmuz 1912 tarihli aldığı Balkanlardaki son terhis kararı üzerine verilen seferberlik emri ciddi kargaşaların yaşanmasına sebebiyet vermiştir.(Feyzioğlu, 2016: 202). Balkan Muharebeleri öncesinde halk arasında çeşitli galeyanlar görüldüğü halde devlet bunları teskin etmek üzere Rumeli Kita'sinda bulunan askerlerin terhisi yoluna gitmiştir. Dönemin hükümeti de bölgede eğitim halinde bulunan 120 bin askeri terhis etmek suretiyle gaflet göstermiştir.(Türkgeldi, 1987: 57). Şehremini Operatör Cemil Paşa "Biz harb edecek halde değiliz; bu askerle harb olmaz. Zat-ı Şahaneye söyleyin, muharebenin önünü alsinlar" derken esasında durumun vahametini de gözler önüne sermekteydi.(Türkgeldi, 1987: 58).

Savaş yıllarının Harbiye Nazırı ve Başkomutan vekili Nazım Paşa'nın Sadrazam Ali Paşa'nın damadı olması münasebetiyle hızla yükselmesine yetmişti. Öyle ki kendisi askeri otoriteyi külhanbeyliği ile karıştıran yapısıyla bilinirdi. Korgeneral üniforması ile Beyoğlu'nda sarhoş gezmesi münasebetiyle Sultan II. Abdülhamid tarafindan Erzurum'a sürülüp İstanbul'dan uzaklaştırılsa da daha sonraları "Hürriyet Kahramanı" unvanını bir şekilde üstüne almıştı.(Karal, 2011: 306). Komuta makamları karışıktı, görevleri belli değildi. Mesela harp harekâtı tasarısına göre Taşlıca Müfrezesinin görevi bilinmiyordu.(Çakmak, 2012: 121). Nazım Paşa Balkan savaşı 


\section{Balkan Çözülmesi ve Osmanlı Cephesinden Balkan Devletleri Algısı}

başlayacağ1 sıralarda bile, Balkan kuvvetlerine karşı yürütülecek savaş planlarını görmemiş bulunuyordu.(Türkgeldi, 1987: 60).

Balkanlarda, Ruslar ve genişlemek sevdasında olan Osmanlı İmparatorluğundan doğan diğer devletler Osmanlı Devleti'ne ve birbirlerine karşı mücadelelerini sürdürürken, Osmanlı yönetimi kendisine karşı olanlara karşı tedbir almadı ve bu devletlerin aralarındaki sürtüşmeleri artıracak herhangi bir girişimde bulunmadı. Balkanlardaki gelişmelerin imparatorluğun temelini sarsacak olaylar olduğunu değerlendiremedi(Görgülü, 1993: 9).

Tanin Gazetesi harbin başladığı günlerde attı̆̆1 manşetle Balkanlara dair olayların kamuoyu üzerindeki psikolojisini de yansıtmıştır. 8 Ekim Karadağ'ın Osmanlıya harp ilanı halk arasında adeta sevinçle karşılandığı gibi sonraki gün Tanin gazetesi "Hele Şükür Harp Başladı" şeklinde manşet atmaktaydı.(Tanin 1912:1). 8 Ekim 1912'de Başkomutanlıktan 2.'nci Ordu Müfettişliği'ne şu telgraf geldi: “Karadağ devleti harp ilan etmiştir. Bulgaristan, Yunanistan ve Sırbistan'ın yakında düşman olmaları beklenmektedir. Seferberlik ve toplanmanın hızlandırlması, sinırların kapatılmasına ilişkin tedbirlerin vakit geçirmeden alınması önemle rica olunur" (Çakmak, 2012: 119). Öte yandan merkezde harbe girilmesi konusunda israr sürerken savaşa katılacak kimseyi bulmakta güçlük çekildiği söylenebilir. Yerel halkın gitmesi şöyle dursun, İpek ve Yakova redif taburları bile toplanamıyordu(Çakmak, 2012: 121). Balkan savaşının başlayacağı sırada ordunun morali temelinden sarsılmış bulunuyordu. Anlamını kavrayamadığı Yemen, Makedonya ve Arnavutluk ayaklanmalarının bastırılmasından yıpranmıştı. Uzun süre silahaltında tutulan erler askerlikten yılmıştı. Askere alınan yedek erler ise trenlere zorla indirilmekteydi(Karal, 1911: 308).

Osmanlı İmparatorluğu'na isyana kalkışan Balkan milletleri aslında her şeyin farkındaydılar. Osmanlı' nın içinde bulunduğu bezgin ve yorgun tablo hiç şüphe yok ki onlarında gözlerinden kaçmayan durumlar dâhilindedir. İçişlerindeki çekişmeler, hükümet ile ordu arasındaki çatışmalar ve ordunun emir komuta kademesindeki sıkıntılar Osmanlı' nın bir parçası olan ve içişlerine hâkim olan Balkan unsurlarının da malumudur. Mehmet Ali Nüzhet'in, redif askerlerinin her türlü talimden yoksun, yorgunluk ve açlıktan ve kötü idareden maneviyatı bozulmuş birliklerden oluştuğu tespiti (Feyzioğlu, 2016: 206) herhalde Balkan Devletlerinin tamamı tarafından farkına varılmış bir durumdu.

Öte yandan Balkan Savaşları Avrupa gazetelerinin de yakından takip ettiği bir konuydu. Savaşın başladığı günlerde başta İngiliz gazeteleri olmak üzere Avrupa'dan birçok gazete savaş muhabiri İstanbul'a akın etmişti. İngiltere'nin en önemli gazetelerinden Times, Daily Chronicle, Daily Telegraph, Daily Mail, Central News savaş muhabirlerini İstanbul'a göndermişlerdi(Yavuz, 2013: 151). Aynı zamanda basın dünyasının dönemin önemli kaynaklarından olan New York Tımes'da Balkan muharebeleriyle yakından ilgilenerek savaş öncesi ve savaş yıllarında çok sayıda haber yapmiştır ${ }^{4}($ Yavuz, 2013: 154).

4 Balkan savaşları sürecinde Amerikan Kamuoyunu bilgilendiren New York Times özellikle Anavatanlarına savaşmak üzere dönen Yunanlılardan “Türkiye'nin düşmanları” olarak tasvir ettiği Balkan milletlerinin çok fazla şey istediğini ifade etmesi dikkate şayandır.

| Sosyal Bilimler Araştırmaları Dergisi 


\section{Mehmet Ali KARAMAN}

\section{Balkan Devletlerinin Askeri Altyapıları}

Balkanlardaki gergin hava ve dış baskılar bölge topluluklarının bağımsızlık faaliyetlerine kalkışmaları bölgede ciddi bir stres birikmesine sebebiyet vermiştir. Kendileri açısından bağımsızlık Osmanlı açısından isyan şeklinde algılanan Balkan bunalımı öncesi bölgede beklenti içine giren milletler çok ciddi bir altyapı hazırlığı içerisine girmişlerdir. Bu devletler dış bağlantılı olmak üzere pek çok farklı devletle Osmanlı egemenliğine karşı geliştirecekleri bir harekâtta destek sağlamak üzere çeşitli temaslara bulunmuşlardır.

Donanma Mecmuası'nda Yunus Nadi tarafından kaleme alına bir makale dönemin Osmanlı aydınlarının Balkan savaşları ve Balkan hükümetlerine genel duruşu yansıtır niteliktedir.

Bugün Balkanlarda meşgûle-i harp ve cidaliz. Vaktiyle Osmanlı saltanatının birer vilayetleri, belki bir kaçı bir vilayeti hükmünde olan dört hükümet, gerd nefer ez kıyam olarak bize ilan-ı muhaseme ettiler. Hatta doğrudan doğruya ilan-ı muhaseme etmeyerek izzet-i nefs-i milliyemizi cerihedâr eyleyecek metâlib-i serkeşhâne ile ortaya atıldılar ve böylelikle bila zarar bizi top ile, tüfenk ile cevap verme zeminine sevk ettiler. Mevzi budur. Bugün bize hakim olan hissiyat, hatta hadisat budur ve işte bu mecmua çıktığı zaman birçok kısmı tarihe karışabilecek olan hissiyat ve hadisat budur.

Kuvve-i mukâveme-i Osmâniye'nin Balkan Hükümetlerinin müttefik ve müttedid savletleri karşısında kırılmayacağına iman ederiz. Fakat yalnız ve yalnız başımıza Balkan Hükümetleri ile uğraşıyor değiliz. Öyle olsa câna minnet bilirdik. Balkan hükümetlerini tevlîd eden âmal-ı sâbıka-yı siyasiye, hâlâ Balkanlar'da patlayan top ve tüfenk tarrakaları arasında dahi tanin-endâz olmakda bulunuyor.. Evet, biz Balkan Hükümetlerinin müteferrik ve müttefik savletlerinden pervâ etmeyiz. Bununla beraber bir zamanlar bizim ferman bir satvetimiz olan bu hükümetlerin bugün bizim aleyhimize kerden-firâz cüret olmalarndan ibret beyyin olarak, bunlarn tâ bu dereceye kadar sevk ve is'ad eden ılel ve esbâb-ı tedkîk ve mevcûdiyetimize hücum eden müsskilatın kesreti ve azâmetini de iyice ihâta eylemek suretiyle, daha metîn ve zinde azimlere sahip olduğumuz halde, hayata yeni ve müstesna şevk ve gayretlerle sarlmak ihtiyacından da vâreste kalamayız. Müsskilat ne kadar büyük olursa olsun bizi hiçbir vakit ye's ve fütûra düşürecek kuvvet ve kudrete hâiz olamaz.(Yunus Nadi, 1912: 294)

Müdâfaa-1 Milliye gazetesinin 14 Ekim 1912 tarihli nüshasında yayınlanan "Balkanlar' da Harb" isimli makalede yer alan görüşler hem Balkan Devletlerine karşı Osmanlının bakışını hem de Osmanlı aydınının Balkan Harbi ile ilgili genel beklentisini yansıtır niteliktedir. Yazıda yer alan fikre göre harbin başlaması Osmanlı ve Avrupa için son derece olumlu bir sonuç doğuracaktır. Öyle ki bu harp ile Osmanlı adı bir kat daha yükselecek, Avrupa da bu durumdan olumlu yönde etkilenecektir denilmiştir. Çünkü Balkanlarda hâkim olan problemli havanın Avrupa'yı da olumsuz etkilediğini, harbin başlangıcıyla bu havanın dağılacağı görüşü savunulmuştur. Yazının devamı şöyledir;

Osmanlı ordusunu Balkan hükümetleri saire-i müttefikesi ordularnın mağlup edemeyeceği kuşkusuz ve aşikâr bir şey olup, buna itiraz edecek bir ferd bulunmaz. Bâhusus Osmanl ordusunun sorumluluklarna müretteb vazife-i mühimmeyi her cihette ifâ etmeye 


\section{Balkan Çözülmesi ve Osmanlı Cephesinden Balkan Devletleri Algısı}

muktedir gayet değerli kumandanlar idaresinde bulunduğu unutulmamalıdır(Müdâfaa-ı Milliye, 1912:175).

Mezkûr makale aslında savaş döneminde kamuoyunun moral ve motivasyonunu üst seviyede tutma adına kaleme alınmış bir yazıdır. Basın organlarının bu gibi yaklaşımlarıyla Balkan Savaşlarında olduğu gibi Birinci Dünya Savaşı esnasında da karşılaşmak mümkündür. Genel bakımdan Osmanlı kamuoyunu bilgilendirme açısından Balkan savaşları öncesinde ve savaş sırasında basın organlarında Balkan devletlerinin askeri ve stratejik alt yapılarına fazlaca yer verilmiştir. Öyle ki devletlerin askeri teşkilatlanmalarının yanı sıra, askeri eğitim birimleri, emir komuta kademeleri ve ağır silah sayılarıyla ordularının eğitimlerindeki dış bağlantılara kadar yer verdiğini görmekteyiz. Bunlara her devlet açısından birkaç örnek vermek mümkündür.

"Askerlik nokta-i nazarından nazar-ı ehemmiyete alınabilecek yegâne düşman ordusu Bulgar ordusu olup bu da yillardan beri harp için pek ziyade bir ehemmiyet ile hazırlanmakta idi" (Müdâfaa-ı Milliye, 1912: 175).

Bulgar ordusu ile bir başka görüş ise Osman Nuri imzasıyla Asker Mecmuasi'nda yer almıştır. Mevcut yazı Bulgar ordusunun genel ahvalini anlatmakla birlikte istatistiki rakamlar ve Bulgaristan ordusuna ait muhtelif siniflara ait sayısal veriler aktarılmaktadir.

"Bulgaristan'da bu son senelerde ordunun tensikatına büyük bir gayret-i vukuf ile çalışılmış, mevcud hazırı mütemadiyen yeniden birçok kıtaat teşkil ve tensikât ta'dil edilmiş olduğundan Bulgaristan ordu teşkilatı tebeddülâta uğramıştır..

Hizmet-i Nizamiyede

Silahaltında piyade 2 sene, sintf-ı sâire 3 sene

İhtiyatta piyade 18 sene, sinnf-ı sâire 16 sene

Milisde

Tertîb-i evvel Piyade4 sene, sinıf-ı sâire 5 sene

Tertib-i sâni Piyade 2 sene, sinıf-ı sâire 2 sene

Vakt-i seferde 18 yaşından 20 yaşına kadar olan delikanlılar dahi silahaltına davet olunabilir"(Osman Nuri, 1908: 284).

Karadağ ordu yapısı ile alakalı; Karadağ bilindiği üzere 8 Ekim 1912 tarihinde Osmanlı Devleti'ne savaş ilan ederek Balkanlardaki kaynaşmaya Osmanlı'nın fiili müdahalesinin gerçekleşmesine sebep olan devlettir. Karadağ esas itibari ile ismiyle müstesna dağlık bir alan olduğu gibi halkı da dağlı olmanın verdiği saldırganlık hissini üzerinde taşıyan bir yapıya sahiptir. Bu yapı ordularına da yansımakla birlikte orduları Ruslar ve İtalyanlar tarafından eğitilmiştir. Esas itibari ile pek çok eksikliğin olduğu kabul edilen Karadağ ordusunda ortalama muvazzaf askerlerin 30 yılı mecburi, 13 yılı ihtiyat olmak üzere toplamada 43 yıl askerlik hizmetiyle mükelleftirler.(Mehmet İsmail, 1908: 12) 5 .

Karadağ terakki-i askeriyesi nokta-yı nazarından celb-i dikkat olan bu mekteb hiç şüphe yoktur ki ayrica bir ehemmiyete sahiptir. Çünkü bu memleket Balkanlarda bir muharebe zuhur ettiği takdirde kendi kuvve-i askeriyesi dâhilinde oldukça ehemmiyetli bir rol oynayabilecektir.

\footnotetext{
${ }^{5}$ Mehmet İsmail, 'Sırp ve Karadağ Orduları', Asker Mecmuası, S.13, s.12.
} 


\section{Mehmet Ali KARAMAN}

Karadağ zabitanı tahsil ve terbiye-i askeriyelerini ya Çetine'deki Mekteb-i Harbiye'de ve yahud Rusya ve İtalya hatt-ı terakkiyada görürler idi. Lakin bu tahsil matlub derecede esash ve metîn olamazdr. İşte bu nakiseyi tamir etmek maksadıyla 25 Nisan 1911 tarihinde emirnâme-i krâlî ile tesis-i takrir eden zâdegân gönüllü efrâdı mektebinin resm-i küşadı geçen teşrin-i evvelin 24. günü icra olundu.

Mektep talebeleri 11- ile 15 yaşında bulunan zâdegân evlâdetten teferrik olunur ise de evvel emirde bizzat Karadă̆ Kralı tarafindan intihab edilir. Mektebe duhulleri takdir edilenler ayrica bir muayene-yi tıbbıyeye bilahare bir duhul-ı imtihanat-ı geçirmeye mecburdur. Ancak lüzum olan zâbitanın mikdar-ı seneviyesi $15^{\prime}$ e bali' olduğundan ve diğer tarafdan Karadă̆ hükümetinin vesâit-i takdiyesi mahdûd bulunduğundan mektebe her iki senede 25 çocuktan fazla talebe alınmaması tensîb edilmiştir. (Müdâfaa-ı Milliye, 1912: 7).

5 Teşrin-i evvel 1324/18 Ekim 1908 tarihinde, sonraki nüshalarını İstanbul'da yayınlayan Haftalık Risâle-i Askeriye "Karadağ Ordu Teşkilatı" başlıklı bir yazı dizisi ile Karadağ ordusunun bütün ayrıntılarını aktarmaktadır.

Balkan hükümâtı arasında askerlikte en geri Karadă̆ hükümeti olup, ordusu hâl-i hazır ordularına pek az benzer. Teşkilat-ı ahvali coğrafyasıyla ahalisinin teba'ine göre yapılmışıtır. Karadağlıların cengâverliği ve vatanperverliği ma'lum bir keyfiyettedir. Karadağ'ın teşkilat-ı askeriyesi Prens Danilo (1851-1860) tarafindan icra edilmiştir. Sonra şimdiki Prens Nikita tarafindan 1860 senesinde Sirp muallimlerinin muavenetiyle orduyu Sirp usulünde tanzim ederek yeni bir hatve atıldı. O zaman Sırbıya Karadağ hükümetine 5000 tüfenk, 1 cebeli bataryası ve bir miktar cebehane verdi. Karadağ yine milis tarzını muhafaza etmek üzere Fırka, Liva, Tabur ve bölüklere taksim edildi. Firkalar 2 livadan, livalar 4 alay, 6 taburdan, taburlar 6 bölükten, bölükler 100 neferden mürekkeb idi.

Şimdiki Karadă̆ ordusu yine milis usulündedir. Ahalinin 18'den 25 yaşına kadar olanlarından silah taşımaya muktedir olanlar askerdir. Ordu iki kısma ayrılmıştır. Muvazzaf ordu, 18'den 25 yaşına kadar olanlar; ihtiyat ordusu kırk altıdan atmış yaşına kadar olanlar.

Makalede sıhhiye ile ilgili bir tek askeri tıbbiye varlığından bahsetmektedir. Fakat yeterli askeri hastanenin ve sıhhiye memurlarının olmadığı bilgisinin verildiği makalede hastalanan askerlerin Danilograd, Nikşik ve Podgorica'daki belediye hastanelerinde tedavi edildikleri aktarılmıştır.( Haftalık Risâle-i Askeriye , 1908: 477).

Müdâfaa-ı Milliye gazetesinde yer alan bir tespite göre Surbistan ve Karadağ ordusu için şu ifadelere yer verilmiştir; "Karadağ ile Sırplar bunlarda harpte pek müthiş bir darbe yiyecek adi çeteler kabilindedir. Fransa Ayan azasından Mösyö dö Turnel Konstan, Kral Nikita'ya hitaben neşrettiği açık mektupta Karadağlı hakkında bu hükmümüzü tasdik ediyor(Müdafaa-ı Milliye, 1912:175).

Metin Gazetesinde yer alan haberde ise şu yorumlara yer verilmiştir;

Askerlik hizmeti kanunla belirlenmiş ve yirmi yaşından elli yaşına kadar bütün halkı kapsamaktadır. Askerlik hizmetinin 18 ay ile 2 sene arası ordu dairesinde, sekiz senesi ihtiyatından yedi senesi, birinci stnıf miliste ve yedi senesi de ikinci sinıf miliste olmak üzere dört devre halindedir. Kral ordunun komutanıdır. Ancak Harbiye Nazırı ile asakir-i muzaffer Başkumandanı namı altında kişilerin komuta ve kontrolünde bulunmaktadır. Sırp ordusu 13 kısımdan ibarettir. 1907 senesinde alelade asker bütçesi 20.608.000 Franktır ki 906 bütçesinden

\section{Social Sciences Researches Journal}




\section{Balkan Çözülmesi ve Osmanlı Cephesinden Balkan Devletleri Algısı}

\section{7 bin frank fazladır mesarif-i fevkalade ise 64.000.000 franktır(Metin Gazetesi, 1908:2).}

Karadağ ordu teşkilatı ile ilgili Daire-i Sedaret Tahrirat Kalemi'nden çıkan yazıda Karadağ Hükümeti'nin istihzârât-1 fevkallâdede bulunduğu Kolaşin-i Bâlâ'da bir hayli cephâne ile bir miktar top ve topların isti'mâli için biröok asker mevcud olup topçuların Rus askeri olduğu Kosova Vilâyeti'nin iş'ârına atfen Dâhiliye Nezareti Celilesi'nden bâ-tezkire bildirilmekle seri'an lâzıme icrasıyla neticesinin inbâsına himmet.(BOA, A.MKT.MHM,736/22: 25 Haziran 1327).

Asker mecmuasında yer alan bilgiye göre de Sırbistan'da on sekiz yaşından elli yaşına kadar her ferd hizmet-i askeriye ile mükelleftir. Hizmet-i askeriye yirmi bir yaşından kırk beş yaşına kadar yirmi beş senedir. Hizmet on sekiz yaşından yirmi yaşına ve kırk altı yaşından elli yaşına kadar sekiz senedir. Birinci sınıf ve ikinci sınıf daimi orduda ve üçüncü sınıf yeni mustahfız memleket muhafazasında hizmetlidir. Mekteb-i aliye talebesi altı ayı tahsil terbiye görmüş piyadeler on dört ay ve hayvanlarını birlikte getiren süvariler yalnız 1 sene hizmet ederler.(Mehmed Esat, 1908: 12).

1829 yılında Osmanlı İmparatorluğu'na karşı bağımsızlı̆̆ı ilk elde eden Yunanlılara karşı duruş biraz daha farklı ve detaylı bir çerçevede olmuştur. Balkan savaşları öncesinde 1897 yılında yapılan Türk-Yunan Harbi sonrasında Osmanlı ordusunun Atina'ya kadar dayanması belki de Savaş yanlılarını genel bir Balkan çatışması için cesaretlendiren durumlardandı. Yunan ordusunun bu çerçevede değerlendirilmeye tabi tutulduğu dış bağlantılı kısıtlı imkânları ve bölgedeki milletler içerisinde beklentisi en yüksek olan milliyetçi söylemler sahibi olarak varlık gösterdiklerini söylemek mümkündür. Yunan isyanını tertipleyenlerden olan Fransızların Napolyon ile başlayan müdahaleleri Müdafaa-ı Milliye gazetesinde Şubat 1912 tarihinde yer alan "Yunan Ordusunun Son Teşkilat ve Tensikatı" başlıklı yazıdan da anlaşılacağı üzere Balkan Savaşı öncesi yıllarına kadar devam etmektedir. Öyle ki Fransız generallerinin Yunan ordusunun bütün yönleriyle yapılandırılması konusunda yapılan çalışmalar ve ortaya koyduğu projeler makalenin konusunu oluşturmaktadır.(Müdâfaa-ı Milliye, 1912: 4)..

Yukarıdaki örneklerden de anlaşılabileceği gibi Osmanlı Devleti nezdinde Balkan orduları aslında yakın takibe alınmıştı. Basına yansıyan yönüyle bile oldukça fazla ayrıntı tespitlerin elde olduğu bir ortamda yapılan savaştan mağlubiyet ile ayrılmak sonucuyla karşılaşıldığında Osmanlı askeri yapısının ne kadar eksik bir durumda olduğunu söylemek yanlış olmasa gerek.

\section{Balkan Devletlerinin Hazırlıkları ve Osmanlı Devleti'nin Tedbirleri}

Osmanlı Devleti'nin XIV. yüzyıldan itibaren gerçekleştirdiği fetih hareketleri Balkan unsurları üzerinde her zaman için işgal etkisi yapmıştır. Balkan toplumları durumu Türklerin bölgeyi işgal ettikleri algısı üzerinden değerlendirdiğinden Osmanlı kalmak ya da Osmanlı yaşamak hissiyatı zaman zaman ağır bassa da bilinçaltında yatan bağımsızlık ve hürriyet hırsı her fırsatta kendini hissettirmiştir. Bu konuyu duygusal açıdan ele alan bazı tarihçiler fütuhat ve cihat mantığıyla yaklaşarak realiteleri görmezden gelmişlerdir. Bu sadece belli kitleleri etkilese de başta Slavlar ve Rumlar ile Bulgarlar ve diğer Hristiyan unsurlar arasında Türk ve Müslümanların

| Sosyal Bilimler Araştırmaları Dergisi 
bölgede işgalci olarak algılanmış olmaları gerçeğini değiştirmemiştir. Osmanlı ruhu ve anlayışının oturtulması için Merkez özellikle 18. Yüzyıldan sonra Gayrimüslimleri devşirmeden olduğu gibi önemli vazifelere getirmişse de Batı́nın kışkırtma politikalarının önüne geçilemedi. 1878 Berlin Konferansına Osmanlı Devleti'ni temsilen Rum Karatodori Paşa'nın gitmesi dahi bu algıyı değiştirmedi.

Hemen her firsatta bağımsızlık planları yapan Balkan devletleri XIX. yüzyılın ikinci yarısından itibaren ve XX. yüzyıl başlarında çeşitli hazırlıklar yaptılar. Bu hazırlıkların başında diplomasinin yanı sıra askeri yığınak ve militer tedbirler dikkat çekici niteliktedir. Sırbistan - Karadağ, Yunanistan, Bulgaristan ve Romanya uluslararası diplomatik diyaloglara hız kazandırmışlardır. Balkan devletlerinin ittifak halinde oldukları ve özellikle Avusturya ve Rusya'nın desteğini aldıkları Kosova Vilayeti Tahrirat Kaleminden çlkan 23 Ocak 1912 tarihli belgeden anlaşılmaktadır.(BOA, BEO, 3993/299449 10 Kânûn-1 Sânî 1327). Bunun yanı 1sıra, sınıra Balkan Devletlerinin askeri yığınak yaptıkları, redif askerlerini silahaltına aldıkları ve birbirleriyle ittifak arayışlarına girdikleri de yine dönemin çeşitli yazışma ve telgrafları arasindaki kayitlarda mevcuttur.(BOA, BEO, 3993/299449, 10 Kanun-i Sâni 1327).

Çıkması muhtemel harbe hazırlık için Balkan Devletlerinin sınıra silah ve cephane yı̆̆maları bölgede görev yapan yetkililerin dikkatlerini çekmekteydi. Osmanlı Devleti için tehlike teşkil edecek bu türden hareketlilikler tespit edildiği anda merkeze bilgi verilerek tedbir alınması istenmiştir.(BOA, BEO, 4074/305487, 5 Ağustos 1328). Savaş öncesi bölgede kontrolü elde tutmak ve psikolojik olarak halk arasında da endişe yaratmak izlenilen politikalar arasındaydi. Bulgaristan'da bulunan Emniyet-i Umumiye istihbarat memurundan alınan rapor içeriğine göre Bulgaristan Hükümeti tarafından otuzar, kırkar kişilik çeteler tertip edilmek suretiyle Makedonya sınırının geçildiği ve bölgede karışıklık çıkarılmaya çalışıldığı bildirilmektedir.(BOA, DH. SYS, 29/3-1, 26 Temmuz 1326). Yine Bulgarların sınıra yığınak yapmaları Selanik Valiliği tarafından merkeze bildirilmektedir. Benzer bir vesikada da Yunanlıların sınıra yığınak yaptıkları ve İtalyanların Arnavutluk üzerinden Karadağ'a silah naklini gerçekleştirdiği Viyana gazetelerinde yer aldığı gibi bu durum Babıâli Evrak Odası tarafından kayıt altına alınmıştır.(BOA, BEO, 4081/30606423, 23A ğustos 1328). Osmanlı Devleti'nin konu ile ilgili yaptığı istihbarat neticesinde ise Balkan Devletleri cevaben bu yönde yaptıkları yığınak vesaire hazırlıkların savaşa yönelik olmadığ1 yönündedir.(BOA, BEO, 3955/296602, 13 Teşrin-i Evvel 1327). Mevcut vesikalardan anlaşıldığına göre Balkan çözülmesi öncesinde Osmanlı Devleti tehlikenin farkındalığıyla tedbirler alma yoluna gitti. Bunlardan en çok dikkat çekeni Balkan Devletlerinin askeri yığınak ve tedbirlerini mercek altına almasıdır.

\section{SONUÇ}

Osmanlı Devleti'nin sıkıntılı gidişatının en önemli safhasını Balkan sorunu teşkil eder. Balkan devletlerinin kendi bağımsızlıkları için başlattıkları isyan girişimleri ve sonucunda kopmaları Osmanlı Devleti'nin İmparatorluk vasfinın kaybedilmesine sebep olmuştur. Son dönem Osmanlı harpleri içerisinde büyük dersler alınmasına 


\section{Balkan Çözülmesi ve Osmanlı Cephesinden Balkan Devletleri Algısı}

sebep olan bu çatışma ve ayrılık hali Said Halim Paşa'nın deyişiyle "Ĕğer hadiselerin ve vakalarn dili siyasi nutuklar ve vaadler kadar değerlendirilseydi, Balkan Harbinden almamız gereken büyük ders, maneviyatımızda daha derin tesirler bırakırdı."

Bu gelişmeler yaşanırken Balkan devletlerinin askeri altyapıları Osmanlı ordusu tarafından mercek altına alındı. Balkan devletlerinden başta Bulgaristan olmak üzere, Romanya, Yunanistan, Sırbistan ve Karadağ ordu teşkilatlarının bütün ayrıntısıyla incelendiğini görmekteyiz. Yapılan bu çalışmalar dönemin askeri anlayışları dâhilinde olup, savaş hazırlığı yapan bir ordunun bütün sorularına cevap verir niteliktedir. Elde edilen bütün tespitlere ve olumsuzluklara rağmen devletin savaşa girmesi engellenememiştir. Başta Rusya ve bazı Avrupa devletlerinin açık askeri ve siyasi desteğini alan Balkan toplumları kendi bağımsızlık mücadelelerini vermekten geri durmadilar.

Esas itibari ile Osmanlı'da askeri kanat ve aydın kesim ikiye bölünmüştür. Memleketin gerçek durumunu göz önüne alıp sağlıklı değerlendirmeye tabi tutan kesim savaşa girmenin bir yıkım olacağını, beraberinde ölüm ve felaketin geleceğini söylemekten geri durmamıştır. Bununla birlikte büyük bir kesim ise Avrupa' da husule gelen bağımsızlık fikri ile hareketlenen Balkan coğrafyasına müdahale etmek gerekliliğini savunmaktaydı. Gazi Ahmed Paşa Hükümeti bu ikinci grubun psikolojik baskısı altında savaş kararı almak zorunda kalmıştır.

Hafız Hakkı Paşa ise Balkan Savaşları sonrası hem kendi hem de devleti yönetenlerin içinde bulunduğu halet-i ruhiyesini yansıtan ve "Bozgun adını verdiği hatıratında şu yorumu yapmıştır: "Bugün Manastırın Orizar ovasında, Gâvat geçitlerinde, Pirlepe Dağları'nda kardeşim kadar sevdiğim nice canlar yatıyor... Kumanova tepelerinde, Kosova Sahrasında Siroz'un altın ovalarında yüzbinlerce kardeş ve kız kardeşimizin ruhları, bizlere vazifesini yapamayan bozgun âfetine kapılarak o candan aziz toprakları, düşmanlara bırakan orduya, melûl ve sitemkâr bakıyor.

Yüksek hayaller, şairâne tasavourlar uyandıran Bursa'nın Keşiş Dağı, Şelânik'in Beyaz Kale bahçesinden beyaz şâhikalariyle görünen ve dünkü Yunan hududumuzda yükselen Olemp'i, Tesalya ovalarını, Çatalca'yı, Dömeke'yi hazin hazin düşündürüyor. Manzarisiyle benliğime, ruhuma kuvvet veren Fâtih minarelerinden bir sürü ruhlar bana "Ey Meşhed'i bırakan bedbaht ordunun subayı! Hâlâ nasıl yaşıyorsun!» diyor. Bütün ordunun bozgunlukları omuzlarmı çökertiyor, yüzümü yerlere kapatıyor. Kan ağlayan kalbim kalan vatan parçalarının bütün güzellikleri için kardeşini kaybetmiş bir insan şefkatiyle titriyor. Güzel Rumeli'nin acl, ateşli hâtıraları bana Konya, Erzurum, Bă̆dat, Mekke için yavrusu çalınan bir kartal şefkati ve hırçınlı̆̆l veriyor."

Biri dönemin en üst düzey devlet adamı olan Said Halim Paşa, bir diğeri askeri kanadın önde gelen ismi olan Hafız Hakkı Paşa'nın aslında bu sözleri pek çok şeyi ifade etmektedir. "Balkan isyanı ya da Balkan milletlerinin bağımsızlık mücadelesi" bu tartışmalar sübjektif yorumlarla sürerken aslında gerçek bir ittihad olan ve birbiriyle yüzyıllarca birlikte yaşamış unsurların parçalanma sürecine karşı yaklaşım "Balkan Çözülmesi" yaklaşımıyla adlandırılabilir. Balkan çözülmesi XIX. yüzyılda başlamış sonrasında uluslararası toplantılarda ele alınmış ve sonuçta da bir sonraki asra taşan sürede çözülme gerçekleşmiştir. Balkan çözülmesi bütün Balkan toplumları için

| Sosyal Bilimler Araştırmaları Dergisi 


\section{Mehmet Ali KARAMAN}

oldukça acı ve sıkıntılı dönemlerin yaşanmasına sebep olmuştur. Bu süreç XX. yüzyılın sonlarına kadar devam etmiş, hâlihazırda da bölgede uzun dönemlerden beri yaşanan siyasi ve sosyal çalkantılar ile birlikte ölüm ve dramların açtığı yorgunluğu üzerinde taşımaktadır.

\section{KAYNAKÇA}

BOA, A.MKT.MHM,736/22 (25 Haziran 1327) :

BEO, 3955/296602 (13 Teşrin-i Evvel 1327) : /3993/299449 (10 Kânûn-1 Sânî 1327) : $3997 / 299737$ (17 Kânûn-1 Sânî 1327: 4074/305487 (5 Ağustos 1328): 4081/306064 (23 Ağustos 1328).

DH. SYS, 29/3-1 (26 Temmuz 1326),

HR.SYS.2043/3-1,12,13,15.

MV. 175/56 (20 Mart 1913) :175/79, (26 Mart 1913).

MUHTAR Ahmed, "Balkan İttihadı”, Metin Gazetesi, 8 Ağustos 1324 (21 A A gustos 1908), S.12, S. 2.

ÇAĞ, Galip, Avrupa'nın Ötekisi Balkanlar, Çankırı 2012, S.12-13.

ÇAKMAK, Fevzi, Batı Rumeli'yi Nasıl Kaybettik, Türkiye İş Bankası Kültür Yayınları, İstanbul 2012.

DJUVARA, Trandfer G. Türkiyénin Paylaşılması Hakkında Yüz Proje, Çev. Pulat Tacar, Gündoğan Yayınları, İstanbul 1999.

FEYZİĞLU, Hamiyet Sezer, "Hatıraların Işı̆̆ında Balkan Savaşları", DTCF Dergisi, 56/2, 2016, ss.200-213.

GÖRGÜLÜ, İsmet, 10 Yillık Harbin Kadrosu 1912-1922, TTK Yayınları, Ankara 1993.

HOBSBAWM, Eric Milletler Ve Milliyetçilik, Ayrıntı Yayınları, İstanbul 2010.

HOBSBAWM, Eric Yeni Yüzyılın Eşiğinde, Yordam Kitap, İstanbul 2007.

INALCIK, Halil, “Türkler ve Balkanlar”, Bal-Tam Türklük Dergisi, Prizren Eylül 2005, ss.9-32.

İsimsiz, "Karadağ Zadegân Gönüllü Efradı", Müdâfaa-I Milliye, S.25, 15 Şubat 1327/M. 28 Şubat 1912, S.7.

İsimsiz, "Birazda Komşularımızı Tanıyalım Sırp Ordusu", Metin Gazetesi, 8 Ağustos 1324 (21 Ağustos 1908), S.12, S.2.

İsimsiz, "Yunan Ordusunun Son Teşkilat Ve Tensikatı", Müdafaa-I Milliye, S.25, 28 Şubat 1912, S.4.

İsimsiz, "Balkanlarda Harb", Müdâfaa-I Milliye, S. 40-41, 1-15 Teşrin-i Evvel 1328/14-28 Ekim 1912, S.175.

İsimsiz, "Balkanlarda Harb", Müdâfaa-I Milliye, S. 40-41, 1-15 Teşrin-i Evvel 1328/14-28 Ekim 1912, S. 175.

İsimsiz, "Balkanlarda Harb", Müdâfaa-I Milliye, S. 40-41, S.175.

İsimsiz, "Karadağ Ordu Teşkilatı", Haftalık Risâle-İ Askeriye, S.15, 28 Kanun-1 Evvel 1324, S..477. Karaman,

KARAL, Enver Ziya, Osmanlı Tarihi, C.9, TTK. Yayınları, Ankara 2011.

KARPAT, Kemal, “Balkan”, DİA İslâm Ansiklopedisi, C.5, 25-32. 


\section{Balkan Çözülmesi ve Osmanlı Cephesinden Balkan Devletleri Algısı}

Kolağası Mehmet Esad, 'Sırp ve Karadağ Orduları: Sırbistan', Asker Mecmuası, S.13, S.12.

MCCARTHY, Justin, Ölüm Ve Sürgün, Ttk, Ankara 2012.

Mehmed Zeki, “Askeri Tayyarecilik", Müdâfaa-İ Milliye, S. 25, 15 Şubat 1327/28 Şubat 1912, S. 1.

Mehmet İsmail, "Sırp Ve Karadağ Orduları", Asker Mecmuasl, S.13, S.12.

HAYTA, Necdet, "Rodos ve 12 Adanın İtalyanlar Tarafindan İşgali ve İşgalden Sonra Adalarm Durumu 1912-1918 ", OTAM , S.V., 1994, ss. 131-144

Osman Nuri, "Bulgaristan Ordu Teşkilâtı", Asker Mecmuası, S.6, S.284.

SERBESTOĞLU, İbrahim, "Balkan Savaşları ve Tabiiyet Sorunu", Tarih Incelemeleri Dergisi, XXVIII / 2, 2013, Ss. 471-486

ŞAHIN, Feyza Kurnaz, "Balkan Savaşları Sonrasında Osmanlı Devleti'nin Kaybettiği Topraklardaki Müslümanları Korumaya Yönelik Hukuki Düzenlemeler" Ubtas 2014, C.I., S.143-166.

ŞAHIN, Gürsoy, 'İngiliz Gazeteci Sır Edwin Pears'a Göre XX. Yüzyılın Başlarında Balkanlar'da Sosyal Yapı ve Birlikte Yaşama Tecrübesi', Ubtas Bildiri Kitabı, İstanbul 2015, C.1, ss.317-344;

TODOROVA, Maria, Balkanları Tahayyül Etmek, Çev. Dilek Şendil, İletişim Yayınları, İstanbul 2013.

TÜRKGELDİ, Ali Fuad, Görüp İşittiklerim, TTK Yayınları, Ankara 1987.

ÖZCAN, Uğur Il. Abdülhamid Döneminde Osmanlı-Karadă̆ İlişkileri, TTK Yayınları, Ankara 2012.

YAVUZ, Fikrettin, “New York Times Gazetesi'nin Gözüyle Balkan Savaşları” Tarih Okulu Dergisi, Y1l:6, S.XVI, ss.147-186

NADİ Yunus, "Hâdisât-1 Câriye Karşısında Hasbıhâl", Donanma Mecmûası, S.31, Eylül 1328/Eylül 1912, s.294-298. 